\title{
招标代理在招标中控制工程造价的对策研究
}

\author{
马金玲 \\ 新疆正鼎工程管理有限公司 \\ DOI:10.32629/btr.v3i8.3291
}

\begin{abstract}
[摘 要] 工程项目中采用招投标方式来实现投标竞争, 对于确保工程质量, 缩短工期, 以及有效降低工程 造价都起着十分重要的作用。招投标是顺应市场经济的发展而产生的,所以招投标以及其阶段造价控制 有非常积极的意义。招标代理机构是在国家招标投标制度产生和不断发展中产生的,作为经济领域的一 个重要服务性机构,招标代理机构主要是在提供综合性、专业化的中介服务给市场主体的同时规范市场 交易的行为,控制市场中的工程造价。然而受到很多因素的影响,在实际的过程中,招标代理机构出现了 很多问题。在此基础上,本文将会对招标代理的现状和出现的问题进行分析并提出一些对策,希望能为以 后的工程建设提供一些帮助。
\end{abstract}

[关键词] 建设工程; 招标代理; 招标阶段; 造价

中图分类号: TU723.2 文献标识码: A

近年来, 在我国改革开放大力发展 经济的大背景下, 建筑项目也不断发展 与变化, 招标制度越来越完善, 工程的招 投标阶段的造价控制在建筑企业的发展 中占据着重要位置。因此, 本文通过对建 筑工程招标阶段造价控制的发展意义以 及存在的问题进行了分析, 并且采用相 应的应对措施, 来提升整个工程质量与 安全以及经济效益。

\section{1 标代理机构概述}

招标代理机构有广义和狭义之分, 狭义的招标代理机构是指接受招标人委 托, 代为从事招标组织活动的中介机构。 而广义的招标代理机构还应该包括专门 从事政府采购活动, 而隶属于政府部门 的招标管理机构。我们这里只讨论作为 市场中介的招标代理机构。

招标代理机构是独立于政府和企业 之外, 为市场主体提供招标服务的专业 机构, 属于市场中介组织。在代办招标过 程中, 招标机构不仅要接受招标人和投 标人的监督, 还要还受到国家法律法规 和社会的监督, 以及执业资格和职业道 德的约束。

从国际范围来看, 作为市场中介的 招标代理机构是以赢利为目的, 通过提 供国内国际招标服务收取佣金的专业化
公司。招标代理机构的主要业务包括: 发布招标通告, 发售国际招标文件, 提供 咨询服务以指导企业投标, 代理投标等。

近几年来我国的招标代理机构从 无到有, 业务从小到大, 累计完成了几 万个招标项目。全国不少省份的招标代 理机构发展极为迅速, 工程代理机构能 为业主提供专业化, 社会化的服务, 使 招标代理活动更加规范, 工程招标代理 机构在招标投标活动中发挥越来越重 要的作用。

\section{2 工程招标代理机构在招标投} \section{标活动中作用}

2. 1 推进了工程建设管理方式社会 化、专业化的发展, 工程招标代理机构是 在《招标投标法》颁布之后应运而生的 新事物, 工程招标代理管理的政策法规 完善招标代理政策法规体系是培育和发 展招标代理市场的重要内容, 是规范招 标代理活动的重要前提和法律基础。它 的引入, 弥补了我国传统的临时 “筹建 组”、“指挥部” 等工程建设管理模式中 存在的弊端, 有助于招标经验的积累。招 标代理机构的产生使我国工程建设的管 理更加符合社会主义市场经济发展的规 范性要求, 工程在建设过程中处于不断 的相互制约与发展之中加快了我国工程
建设管理方式向社会化、专业化方向转 变的步伐

2.2 降低了工程造价, 招标制度是发 达市场经济条件下一种成熟的交易方式， 它能够减少买卖双方的信息不对称, 有 利于买方以较低的价格采购商品提高了 投资效益招标代理制在房屋建筑和市政 基础设施工程中得到普遍施行, 在交通、 铁道、水利、电力、机电、治金等领域 也不同程度实行, 尤其是在2008奥运场 馆、三峡工程、青藏铁路、南水北调等 一批国家重点工程和大中型建设项目上, 工程招标代理制发挥了较好的作用, 推 进了项目顺利施行。

\section{3 招标代理控制工程造价的} 现状

3. 1 对招标控制缺乏市场的导向性。 建设工程项目有内容复杂、专业性强、 政策性强、设计范围广等特点, 项目招标 难度大。在实际的招标工作中, 招标人会 委托招标代理以委托人的身份进行勘 察、设计、施工、设备采购以及监理等 的工作。在建筑工程的招标投标阶段, 对造价的控制有利于控制建设企业的成 本, 节约一定的企业资金, 提高建设企业 的经济效益。但是, 不断变化着的市场经 济环境会影响招标活动中招标代理对造 
价的控制, 缺少了市场的对招标活动的 导向, 引起造成招标单位出现一系列不 好的现象, 比如超投资等, 影响相关企业 的持续健康发展。

3. 2 评价体系不合理。招标过程中不 合理的评价体系, 不仅会影响招标代理 的市场, 而且会影响到招标投标活动的 进行。建设工程招标评价一般采用综合 评估法和合理低价法。综合评估法是指 通过相关部门的市场调研和社会平均建 设成本等条件来制定招标控制的最低价, 当竞价低于最低价时视为低于成本竞价, 按无效报价处理, 这种方法在一定程度 上可以减少串标或哄抬报价现象的出现, 但『方面也不利于形成市场竞争机制。 合理低价法是指通过招标单位在一定区 间内投标报价的算术平均数和招标控制 价或者下浮一定比例进行随机复合, 然 后产生基准数据。但是在复合时相应的 数据会出现一定的变化, 所以这种评价 体系会有很大的随机性, 很可能受人为 因素影响出现串标或哄抬报价现象, 影 响招标工作的进行。

3. 3 竞价方式不合理。现今, 竞价方 式不合理的问题还存在于招标代理在招 标时对造价的控制中, 多数竞价方没有 在竞标过程中充分分析实际生产环境, 没有正确预估市场经济中的风险，招投 标市场方案不符合实际的市场经济的需 求, 影响市场竞价, 同时也会阻碍建筑行 业的规范不利于社会的稳定发展。

\section{4 招标代理在招标中控制工程 造价的对策}

4. 1 完善项目招投标规范。在面对招 标中控制工程造价时出现的问题时, 增
强招标工作服务意识, 并积极采取有效 推进工程项目的顺利建设是招标代理机 构应该做的。为了推进招标工作和对工 程造价控制的顺利进行, 招标代理首先 要充分了解和掌握实际的招标工作并逐 步完善招投标代理规范, 严格按照规范 进行操作, 同时还应学习和践行相关制 度、规定。

4. 2 完善工程项目开标、评标工作。 要实现对工程造价的控制, 招标代理应 完善工程项目的开标、评标系统, 公开招 标的信息和流程, 不断完善制度从而控 制招投标的控制, 奠定建设企业后期发 展基础。招标文件中的合同条款、评价 办法、工程量清单等要进行重点编审。 在充分了解和分析工程项目复杂程度和 特点的基础上, 对经济标、技术标以及商 务标的评分细则和比例进行适当的调整, 禁止严重偏离有效投标报价算术平均值 的投标报价参与基准价计算, 对投标报 价过高或过低的投标文件进行重点审查, 看是否有恶意串标、围标的行为, 这样才 能保证评标方法的合理性和科学性, 有 效预防串标、哄抬报价以及围标行为的 出现。也可以通过电子招标评标系统来 规范清标流程, 提高评标效率。将不符合 报价金额范围的认定为无效投标, 并提 醒未超出的项目投标人在签订合同时列 入风险范围。合理设定招标的暂估价是 指依法按照招标程序来定质定价。

4.3 合理编制控制价及工程量清单。 招标代理要在具体制度要求的基础上合 理编制控制价及工程量清单, 并进行充 分的市场调研, 熟练运用各种计价依据, 对施工单位的施工成本和施工利润等进
行合理分析, 确保工程量清单及控制价 的准确和规范, 为后续的工作进行奠定 数据基础, 有利于工程造价控制工作的 顺利、高效完成。在造价控制工作的实 际过程中, 造价的控制会受招标文件合 同条款设置的影响, 所以要根据国家标 准示范文本来制定合同, 要特别注意重 点章节的具体内容, 责任划分要明确, 例 如在合理约定的基础上变更估价原则、 价格风险范围、合同价格形式、支付和 计量方式、缺陷责任期与保修、竣工结 算等重要的条款。

\section{5 结语}

招标投标期项有利于维护国家和公 共利益、防止贪污腐败现象、节省建设 投资的技术经济活动。在实际的工作过 程中, 要发挥招标代理的重要作用, 调节 好各个方面之间的关系, 坚持公平公开 公正, 在不断的完善招投标规范的过程 中推动招标工作有效性的提高, 进而推 动工程造价控制的顺利进行, 有利于建 设企业的持续、健康发展。

\section{[参考文献]}

[1]田东晖.建设工程招投标管理工 作问题及对策分析[J].纳税,2018,(2):134.

[2]徐海宁.建设工程招标代理及招 标阶段造价管理策略 [J]. 建筑技术研 究,2019,002(011):93-94.

[3]王捷.我国建设工程招标代理 发展现状及对策分析 [J]. 技术与市 场,2016,23(09):252-253.

[4]吴玲.建筑工程造价在招投标过 程中存在的问题分析及对策分析[J].中 国住宅设施,2017,(11):100-101。 